\title{
Uraemic tumoural calcinosis
}

\author{
Muhsen Al-ani, ${ }^{1}$ Konstantinos Parperis, ${ }^{2}$ Christina DeBaun Kelly,
}

${ }^{1}$ Maricopa Medical Center, Phoenix, Arizona, USA

${ }^{2}$ Department of Medicine, Maricopa Medical Center and University of Arizona College of Medicine, Phoenix, Phoenix Arizona, USA

${ }^{3}$ Department of Internal Medicine, Maricopa Medical Center, Phoenix, Arizona, USA ${ }^{4}$ University of Arizona College of Medicine Phoenix, Phoenix, Arizona, USA

\section{Correspondence to}

Dr Muhsen Al-ani,

dr.muhsenalani@gmail.com

Accepted 10 February 2016

\section{DESCRIPTION}

A 22-year-old Hispanic woman, visiting from Mexico, with a medical history significant for endstage renal disease secondary to hypoplastic kidneys on peritoneal dialysis for the past 2 years and hypertension on nifidipine $30 \mathrm{mg}$ daily, losartan $50 \mathrm{mg}$ daily and prazosin $10 \mathrm{mg}$ daily, presented with shortness of breath after missing peritoneal dialysis for 3 days, she was also reporting two large masses over her clavicles that were of indolent onset over the last year. Physical examination showed blood pressure of 191/130, heart rate of $77 \mathrm{bpm}$ and normal temperature, there were crackles on bilateral lung bases and two subcutaneous nodular rubbery masses over the sternoclavicular joints (figure 1). Blood work showed haemoglobin $4.7 \mathrm{~g} / \mathrm{dL}$, blood urea nitrogen (BUN) $137 \mathrm{mg} / \mathrm{dL}$; creatinine $20.87 \mathrm{mg} / \mathrm{dL}$; calcium $10.4 \mathrm{mg} / \mathrm{dL}$; phosphorus $9.7 \mathrm{mg} / \mathrm{dL}$; alkaline phosphatase $240 \mathrm{IU}$; erythrocyte sedimentation rate $48 \mathrm{~mm} / \mathrm{L}$ and parathormone intact was $2308.7 \mathrm{pg} / \mathrm{mL}$, vitamin $\mathrm{D}$

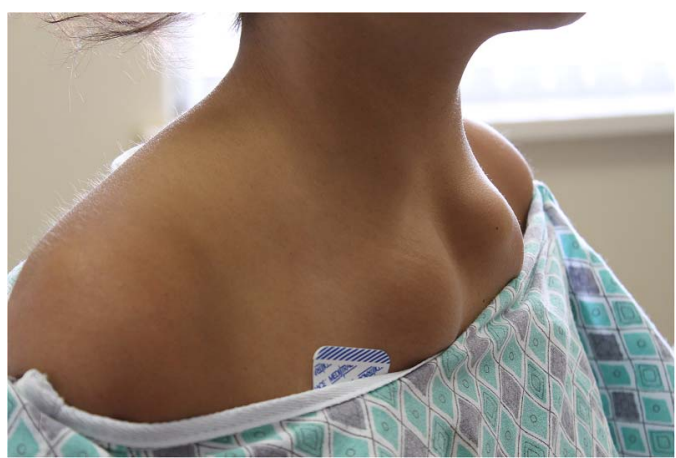

Figure 1 Photograph of the two rubbery nodular masses over the sternoclavicular joints; skin is intact with no erythaema.

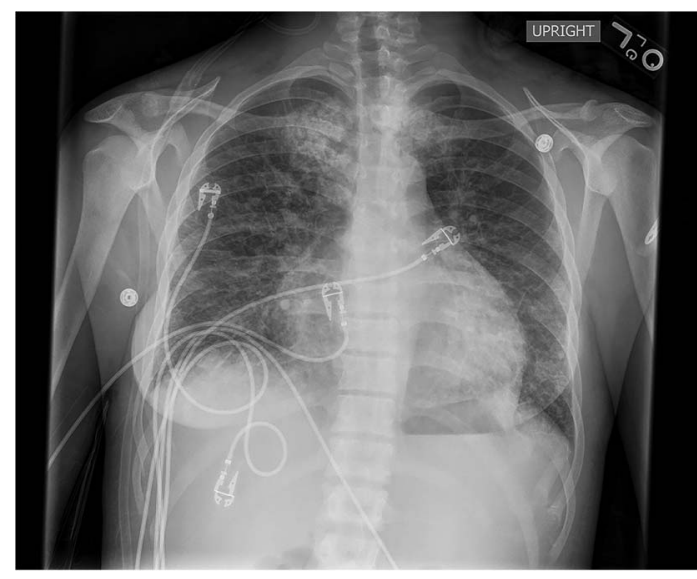

Figure 2 Chest X-ray showing dense calcifications at the sternoclavicular joints, bilaterally.

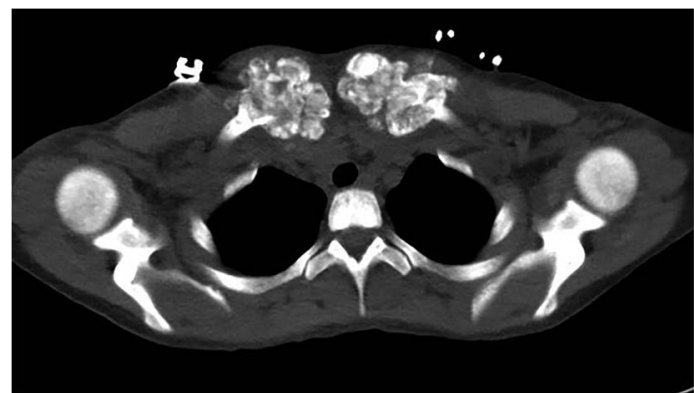

Figure 3 CT scan of the chest, without contrast, showing extensive overgrowth and calcinosis of the bilateral clavicular heads at the sternoclavicular articulation.

level was $18 \mathrm{ng} / \mathrm{mL},(\mathrm{Ca} \times \mathrm{P})=100.88 \mathrm{mg}^{2} / \mathrm{dL}^{2}$ (the $\mathrm{Ca} \times \mathrm{P}$ product should be maintained at level $<55 \mathrm{mg}^{2} / \mathrm{dL}^{2}$ ). Chest X-ray was significant for borderline cardiomegaly, prominent pulmonary vasculature, diffuse coarsely interstitial markings and dense calcifications at the sternoclavicular joints, bilaterally (figure 2). CT scan of the chest showed extensive overgrowth and calcinosis of the bilateral clavicular heads at the sternoclavicular articulation (figures 3 and 4). The patient was admitted and received 3 sessions of haemodialysis with low calcium dialysate over 4 days, she also received blood transfusions for her normocytic anaemia, and we started her on sevelamer carbonate $800 \mathrm{mg}$ three times a day and cinacalcet $60 \mathrm{mg}$ daily. On day 3, her laboratory results had improved with haemoglobin level $9 \mathrm{~g} / \mathrm{dL}$; BUN $85 \mathrm{mg} / \mathrm{dL}$; creatinine $10.23 \mathrm{mg} / \mathrm{dL}$; calcium $8.7 \mathrm{mg} / \mathrm{dL}$; phosphorus $7 \mathrm{mg} / \mathrm{dL}(\mathrm{Ca} \times \mathrm{P})=60.9 \mathrm{mg}^{2} / \mathrm{dL}^{2}$. On day 4 , the patient started feeling better, we recommended further management with parathyroidectomy but she wanted to go back to her hometown to finish treatment.

Tumoural calcinosis is an uncommon type of extraosseous periarticular calcification characterised by large rubbery or cystic masses containing calcium-phosphate deposits. It is more common in end-stage renal disease associated with tertiary hyperparathyroidism but it might occur as an

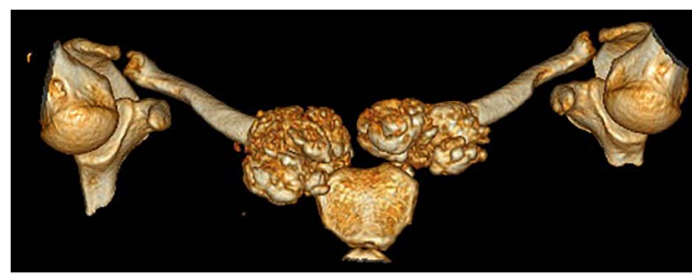

Figure 4 Three-dimensional image from the CT scan of the chest showing tumoural calcinosis over the sternoclavicular joints. 
inherited disease in the setting of normal renal function. ${ }^{1}$ The condition is usually multifocal, occurring around the weightbearing joints or easily overused small joints ${ }^{2}$ - our case showed sternoclavicular joint involvement, which has none of those features.

Medical therapy, including phosphate binders to reduce calcium and phosphate reabsorption, modification of dialysis

\section{Learning points}

- Tumoural calcinosis is a clinical diagnosis confirmed with imaging study.

- High calcium-phosphorus (CaxP) product and secondaryl tertiary hyperparathyroidism play an important role in the pathogenesis of tumoural calcinosis.

- The treatment for tumoural calcinoses is to reduce the serum phosphate levels with phosphate binders, and longer and/or more frequent dialyses with low calcium dialysate to enhance calcium and phosphate clearance. with longer session durations and increased frequency, and the use of low calcium dialysate to enhance calcium and phosphate clearance, can mobilise the calcium deposits of uraemic tumoural calcinosis. ${ }^{3}$

Surgical resection of the calcified mass is the main treatment for the primary type, but should be avoided in haemodialysisrelated types, which are instead often treated with parathyroidectomy. ${ }^{4}$

Competing interests None declared.

Patient consent Obtained.

Provenance and peer review Not commissioned; externally peer reviewed.

\section{REFERENCES}

1 Mitnick PD, Goldfarb S, Slatopolsky E, et al. Calcium and phosphate metabolism in tumoral calcinosis. Ann Intern Med 1980;92:482-7.

2 Chu HY, Chu P, Lin YF, et al. Uremic tumoral calcinosis in patients on peritoneal dialysis: clinical, radiologic, and laboratory features. Perit Dial Int 2011;31:430-9.

3 Yeh SM, Hwang SJ, Chen HC. Treatment of severe metastatic calcification in hemodialysis patients. Hemodial Int 2009;13:163-7.

4 Farzan M, Farhoud AR. Tumoral calcinosis: what is the treatment? Report of two cases of different types and review of the literature. Am J Orthop 2011;40: E170-6.

Copyright 2016 BMJ Publishing Group. All rights reserved. For permission to reuse any of this content visit http://group.bmj.com/group/rights-licensing/permissions.

BMJ Case Report Fellows may re-use this article for personal use and teaching without any further permission.

Become a Fellow of BMJ Case Reports today and you can:

- Submit as many cases as you like

- Enjoy fast sympathetic peer review and rapid publication of accepted articles

- Access all the published articles

- Re-use any of the published material for personal use and teaching without further permission

For information on Institutional Fellowships contact consortiasales@bmjgroup.com

Visit casereports.bmj.com for more articles like this and to become a Fellow 